\title{
ENTRE A PROFÉTICA DE LÉVINAS E A POÉTICA DE GUIMARÃES ROSA: UMA ANTROPOLOGIA DA CARNE DE OUTRO MODO QUE SER
}

\author{
BETWEEN THE PROPHETIC OF LÉVINAS AND THE POETICS OF GUIMARÃES ROSA: AN \\ ANTHROPOLOGY OF OTHERWISE THAN BEING
}

Nilo Ribeiro Junior*

\section{RESUMO}

$\mathrm{O}$ artigo visa pensar a possibilidade de uma antropogênese da humanidade fora das malhas da fenomenologia e da ontologia tal como a propugna o filósofo Emmanuel Lévinas. Isso supõe nuclear seu pensamento em torno de uma significância do non-sens e uma linguagem pósontológica que não traia o Dizer ético originário firmado na relação sem relação com outrem. Trata-se, portanto, de mostrar que a linguagem profética da humanidade fora de si alterada pelo advento do outro reverbera na linguagem poética do literato Guimarães Rosa graças à maneira como a carnalidade humana insurge como uma forma de quiasma que possibilita a intriga entre o discurso profético e poético em função de "outra maneira que ser" da ética da alteridade.

PALAVRAS-CHAVE: Linguagem. Signo. Ética. Alteridade. Carne.

\section{ABSTRACT}

This paper aims to think the possibility of an anthropogenesis of humanity outside the phenomenology and ontology meshes according of Emmanuel Levinas propose. This proposition supposes to nucleate his tought around the significance of non-sens and a postontological language that doesn't betray the ethical Saying originary signed from the relationship with the Other. It treats, therefore, of showing that the prophetic language of humanity outside itself altered by the coming of the Other reverberates in the poetic language of Guimarães Rosa - a Brazilian writer. That's possible thanks to way how the human carnality arises while a kind of chiasmus enabling the intrigue between the prophetic discourse and the poetic in function of the "otherwise than being" of the Ethics of alterity. KEY-WORDS: Language. Signal. Ethics. Alterity. Flesh.

\footnotetext{
* Doutor em Filosofia pela Universidade Católica Portuguesa e professor do Departamento de Filosofia da FAJE - Faculdade Jesuíta de Filosofia e Teologia, Belo Horizonte. Lattes: http://lattes.cnpq.br/8047378549590212.
} 
“[...] só o sentido de outrem é irrecusável, e só ele interdiz a reclusão e o enclaustramento na concha de si. Há uma voz que vem de outra margem. Há uma voz que interrompe o dizer do já dito" (LÉVINAS, 2011, p. 194).

Não há maneira mais encarnada e existencial de filosofar e, portanto, de pensar a condição humana do que profetizar, diria o filósofo franco-lituano Emmanuel Lévinas, no contexto de seus escritos e comentários sobre o Talmude (LÉVINAS, 1982, p.7). Trata-se da tradução ética do Livro hebraico fixado nos séculos III e IV de nossa era, cuja preocupação fundamental se detém sobre o "problema das relações humanas para o qual a questão de Deus é colocada em suspensão de juízo" (1982, p. 169) até que o homem se torne responsável pelo outro. É, pois, a partir da situação ética pré-original que a palavra Deus se significa para além do Ser (p. 162). Eis que nesse caso pretende-se mostrar que, se em princípio Filosofia e Profecia pareceriam opor-se por pertenceram a campos semânticos diferentes, elas mantêm uma proximidade quase congênita em função da humanidade do homem (LÉVINAS, 2011, p.35) que se diz de "outro modo que Ser" quando em contato com a palavra (pro)ferida pela alteridade de outro homem (1987, p. 220).

Em vista de se evitar algum equívoco a respeito do sentido que o autor confere ao termo "profetismo" urge situá-lo no horizonte de sua filosofia do Rosto. Isso supõe desconstruir o sentido habitual dessa palavra a fim de reabilitá-la em função da intriga ética ou das relações eminentemente humanas. Ora, no rol de sua gramática filosófica, o termo é “destituído do imaginário religioso" (LÉVINAS, 1982, p. 8) no sentido de que o profeta fale em nome de uma deidade, tornando-se assim mero instrumento de um oráculo a respeito do “destino trágico da Moïra grega", isto é, em função do castigo imposto aos mortais entregues à pretensão de se tornarem como deuses (LÉVINAS, 1994, p. 30). Também não se assemelha ao poetar, atividade por meio da qual o artista emprestaria sua boca à musa que o inspira. $\mathrm{E} o$ poeta, nesse caso, se diluiria em sua insignificância diante da Majestade do Ser que se diz a si mesmo enquanto ele (ser) se desvela por meio da "retórica das belas palavras, de sua eloquência e de certa nobreza e de uma expressividade que se impõe independentemente da verdade e que seduz seu ouvinte" (LÉVINAS, 1987, p. 207). Segundo o autor, "a poesia é produtora de canto - de ressonância e de sonoridade, que são a verbalidade do verbo ou a essência" (LÉVINAS, 2011, p. 62).

O termo profetismo, portanto, não diz respeito em primeiro lugar a um problema de caráter religioso nem de ordem mitológica, mas associa-se a uma questão eminentemente 
Artigo: Entre a profética de Lévinas e a poética de Guimarães Rosa: uma antropologia da carne de outro modo que ser

antropológica, embora pensada fora do sentido que o humano adquiriu no âmbito da "filosofia moderna da universalidade da razão como vontade boa sem restrições” (LÉVINAS, 1987, p. 184). Por isso não se pode compaginar a profética com o aniquilamento da subjetividade em detrimento da supremacia do sagrado ou do dom do Ser diante dos quais o ser humano não passaria de mero coadjuvante. Ao contrário, no contexto da filosofia da alteridade, trata-se de insistir sobre a condição profética da humanidade - subjetividade - do homem como aquilo que há de mais originário nele quando da "proximidade da alteridade do outro homem" (LÉVINAS, 2011, p.103); concretamente, do outro que de sua condição extra-vagante (retirante) se faz próximo/linguagem no olhar que fala e na fala que vê de outro modo. Esse paradoxo do Rosto faz com que seja dado ao homem enxergar para além e aquém de si e daquilo que se vê à luz do Ser, pois "só o sentido de outrem é irrecusável, e só ele interdiz a reclusão e o enclausuramento na concha de si. Há uma voz que vem de outra margem. Há uma voz que interrompe o dizer do já dito" (LÉVINAS, 2011, p. 194). Graças a essa incondição de outrem, o "homem responde a uma vocação exterior ao Estado, a uma espécie de extra-territorialidade, como aquela da profecia diante dos poderes políticos [...], vigilância outramente que a inteligência política, lucidez que não se limita a se declinar diante do formalismo da universalidade, mas que sustenta a justiça em suas próprias limitações" (LÉVINAS, 1987, p. 185).

Há de se perceber que no léxico levinasiano a profética - não apenas como discurso mas uma maneira "de viver fora de si devotado a outrem que está sempre por-vir" (LÉVINAS, 1987, p. 233) - inaugura no seio da própria filosofia um saber para-doxal a respeito da humanidade do homem. Essa filosofia situa a subjetividade humana "no logos de um pró-logo" que só o encontro com o outro pode justificá-la (LÉVINAS, 2011, p. 27). No contexto desse pensamento o logos anterior a todo logos ontológico visa a acentuar a anarquia e a anacronia do dizer de outrem com relação à sincronia do dito da Razão e do Ser. É, pois, nessa torção na linguagem provocada por outrem que o discurso do indivíduo é destituído da poética, “cujo ideal retroalimenta-se como afã pelo eterno retorno a si mesmo" (LÉVINAS, 2011, p.116).

Por um lado, o homem-profeta não perde sua condição de único porque o encontro com outrem se estabelece em torno da "sensibilidade ética" como linguagem. Tal "sensibilidade ética" diz respeito ao face a face e ao corpo a corpo, inaugurada pela "pele acariciada do eu-corpo pelo olhar do outro" (LÉVINAS, 1997b, p. 278). Portanto, esse saber paradoxal que origina da situação ética põe em segundo plano o diá-logos e o re- 
conhecimento que mormente estrutura a busca do consenso que brota do debate e da discussão marcados pela acalorada argumentação linguístico-racional e pelas estratégias do discurso razoável que se estabelece entre "sujeitos falantes munidos de direitos segundo a igualdade que os nivela" (LÉVINAS, 1995, p. 112). Por outro, a unicidade do sujeito no contato com outrem só se justifica pela significação e pelo discurso de "um logos ilógico", graças à carne exposta a outrem que se diz "no acusativo como Eis-me aqui" feito corpo-para-outrem (2011, p. 103). Revela-se, portanto, na relação travada com outrem aquilo que Lévinas denomina de "subjetividade fora-do-sujeito-sem-reflexão" (1987, p. 233). Em última instância, isso se deve ao corpo feito "signo, cuja significação acontece na significância ética do único". Ele se faz carne para outrem graças à "aproximação do Rosto que vem ao encontro do eu-corpo e o esvazia de sua essência" (2011, p. 116).

Além disso, quando o filósofo franco-lituano se refere à Profética como maneira de dizer a originalidade da humanidade, ele não a dissocia da Poética, isto é, da Literatura, da Escritura, do Livro, sejam eles sagrados ou profanos, provenientes da tradição oral ou escrita de inúmeras culturas e povos e etnias (LÉVINAS, 1982, p. 9). Inspirado no Talmude e nos filósofos judeus, especialmente, em Franz Rosenzweig, "avesso ao pensamento da totalidade e à sin-taxe grega" (1987, p. 82), interessa-lhe afirmar que as escrituras em seu âmago retratam a existência humana tecida na imediação ética do encontro/escuta de outrem; desse Rosto que não se mede pelos logos graças à sua "palavra que vem de uma altura fora do mundo" (LÉVINAS, 1987, p. 153) e que fala desde sua "não-autoctonia" (p. 141).

Daí que em Lévinas (1982, p. 43), Profética e Poética encontram seu ponto de tangência na Ética. Nesse sentido, os textos narrativos e prescritivos (éticos mais que morais) das culturas e tradições recentes ou milenares nos remetem para a experiência de uma afecção primordial, de um trauma anterior ao thauma (admiração), isto é, de uma paixão e de um padecimento avassaladores provocados por esse encontro in-esperado de outrem. Ele que, com seu advento e sua aproximação/linguagem, toca, fere, sulca, afunda, envelhece, escava porque penetra e põe-se (in) no âmago do sujeito sua ideia (do infinito) do Rosto (LÉVINAS, 1987, p. 141).

Entretanto, o ideatum da ideia do rosto implode a ideia que temos dele não tanto pelo "pensamento" do outro (espírito), mas pelo Desejo que outrem põe nesse corpo que sou “quando de sua aproximação vindo de alhures" (LÉVINAS, 1997b. p. 212). Ora, outrem perpassa e atravessa o corpo de uma ponta à outra de modo a deixar a "sensibilidade à flor da pele" (LÉVINAS, 2011, p. 36) sem que o eu-corpo saiba precisar o sentido do enigma daquilo 
Artigo: Entre a profética de Lévinas e a poética de Guimarães Rosa: uma antropologia da carne de outro modo que ser

que the ocorre, ora vivido como uma violência sem injustiça, ora experimentado como um contentamento descontente. De sorte, que a "visitação/aproximação de outrem" (1997b, p. 236) interdita que o eu permaneça o Mesmo, sujeito livre e autônomo ou uma existência referida ao Ser. Ora, o corpo afetado por outrem trai o sujeito a ponto de ele não poder mais permanecer incólume, insensível, indiferente em sua Mesmidade nessa espécie de eterno retorno do eu a si pela ipseidade do ego transcendental ou pela compreensão de si na temporalização do Ser.

$\mathrm{Na}$ imediação ética do encontro com outrem, como in-finito, o outro pró-fere, isto é, põe o desejo do (in)desejável de modo a provocar um ferimento no corpo antes que o sujeito o admita e que disponha de tempo - na imanência da consciência - para conferir significação a esse "e-vento de ser, nessa ex-ceção ao ser" da subjetividade suscitada pela vinda de outrem (LÉVINAS, 2011, p. 28). Afinal, a irrupção de outrem perfura, persegue e ao mesmo tempo perdoa à humanidade - subjetividade - a ponto de investi-la da bondade que advém do bem do Rosto para além da essência. Por isso, a carnalidade ética está destinada a ser "de" outrem.

\begin{abstract}
O caráter excepcional, extraordinário - transcendente - da bondade, resulta precisamente desta ruptura com o ser e com a história. Reconduzir o bem ao ser aos seus cálculos e à sua história - é anular a bondade. A oscilação, sempre possível, entre a subjetividade e o ser, da qual a subjetividade não seria mais do que um modo, a equivalência das duas linguagens, acaba aqui. A bondade dá à subjetividade a sua significação irredutível. (LÉVINAS, 2011, p. 39).
\end{abstract}

Antes mesmo que o sujeito erija-se como autônomo e livre e como ser-no-mundo, como alguém capaz de "acolher" outrem, a afecção provocada pela aproximação/linguagem de outrem esvazia o poder da vontade ou a vontade de poder; o desejo de outrem (LÉVINAS, 2011, p. 85) é vivido na carne na qual o espírito já está contido graças ao desejo desse (in)desejável do outro, não-eu. Diante de outrem, portanto, "não se pode mais poder sobre ele" (1988, p. 48), exterioridade absoluta em seu Rosto de verbo que se faz carne. Inaugura-se assim o paradoxo da condição humana nessa "negatividade" da impotência da vontade. Esta, porém, torna-se impotência "positiva" pela incansável aproximação de outrem que pela palavra do Rosto suscita o desejo de outrem. Essa palavra que inspira e ao mesmo tempo fere provoca um movimento de desinter-essamento e subversão na essência (de si) a ponto de o eu, corpo-obediência ocupar-se de cuidar da santidade e da precariedade de outrem (LÉVINAS, 2011, p.178). 
Outra metáfora que expressa o drama da ética pode ser evocada nesse contexto. Segundo Lévinas, outrem que vem de alhures é alguém cuja chegada surpreende pelas costas, qual um "assaltante que encosta seu punhal na nuca do eu" (LÉVINAS, 1988, p. 210), de modo a forjar uma situação hiperbólica de ameaça de morte "que aliena minha vontade" (1988, p. 214) a ponto de imobilizar a condição de sujeito-livre. Ele encontra-se "refém e obcecado" (2011, p. 103) por essa proximidade indiscernível, imperscrutável e, portanto, sem chances de reagir a essa espécie de emboscada absolutamente sem-sentido (non-sens) segundo os parâmetros de meus poderes.

Acrescenta-se a isso que num lapso de tempo outrem salta de detrás e se posta imediatamente de fronte do sujeito atônito e o interpela/linguagem na nudez de seu Rosto. Configura-se, assim, uma situação desatinada, inóspita, incompreensível, fora dos padrões do saber e do conhecimento racional, por conta dessa situação inaugurada pelo advento de outrem e marcada pela alternância entre o poder de imobilizar e o de ser interpelado pelo sujeito. Se o outro até então golpeava o sujeito por detrás, agora no face a face o fita, acaricia o sujeito com seu olhar vindo de além do Ser (LÉVINAS, 2011, p. 107). Desse modo, o paradoxo inaugurado pelo Rosto nessa ambiguidade que ameaça e que ao mesmo tempo se vê absolutamente "susceptível pela aproximação de mim" (p. 36), destitui o sujeito de sua autoafecção (p. 137) ou de sua ecceidade vital (1997a, p. 25) graças à palavra proferida por outrem. A irrupção de outrem dá origem a uma responsabilidade visceral que advém do seu olhar silencioso a desarticular qualquer discurso supostamente imaginado sobre outrem. Esse ad-vento transporta o sujeito para o rol da linguagem ou da comunicação pura da responsabilidade, anterior àquela situação fundada na liberdade e na vontade.

\footnotetext{
Inscrição da ordem no para-o-outro da obediência: afecção anárquica que se introduz em mim "como um ladrão", através dos fios retesados da consciência, traumatismo que me surpreendeu de uma forma absoluta, a ordem nunca foi representada [...] a ponto de ser só eu quem diz - posteriormente - esta obrigação inaudita [...] Pode-se chamar profetismo a esta inversão na qual a percepção da ordem coincide com a significação desta ordem feita por aquele que a ela obedece. E deste modo, o profetismo seria o próprio psiquismo da alma: o outro no mesmo; e toda a espiritualidade do homem seria profética. (LÉVINAS, 2011, p. 163-164).
}

Assim, outrem pronuncia um Inter-dizer primordial, advindo por uma espécie de sussurro que diz: “Tu não matarás” (LÉVINAS, 1995, p. 114). A nudez, pois, do outro que se faz próximo recorda, por um lado, que o Rosto "se significa a si mesmo" tanto em sua vulnerabilidade como em sua extravagância de outrem. Em sua condição de ab-soluto 
Artigo: Entre a profética de Lévinas e a poética de Guimarães Rosa: uma antropologia da carne de outro modo que ser

(retirado, santo), ele se absolve da relação e se retira do domínio "da caricatura instransponível da imagem que se manifesta na estupidez do ídolo" (LÉVINAS, 1994, p. 138).

Dito de outro modo, na santidade de outrem (retirado, intocável) se expressa o paradoxo da ética. Pois o outro, ao mesmo que se cola ao meu corpo sem me deixar lugar para pensá-lo à distância, é aquele que me permite senti-lo pela voz que acaricia meus ouvidos. Ele me apela à responsabilidade sem me deixar qualquer recurso para assimilá-lo graças à "linguagem primeva que nos aproxima e que me diz de não matá-lo" (LÉVINAS, 1997b, p. 277). Mas se é verdade que ele, o rosto, é passível de ser violentado e assassinado por conta de sua nudez, por outro lado, sua palavra ética plasma no corpo do sujeito um ouvido, uma vez exposto ao seu apelo. Trata-se mesmo de um ouvido-assujeitado a fim de que esse “corpo-todo-ouvido-do-sujeito ferido se faça linguagem, resposta na responsabilidade por outrem" (LÉVINAS, 1988, p. 187).

Enfim, a palavra afiada, cortante e criadora de outrem advém ao sujeito a fim de que seu corpo se faça linguagem na carne para outrem. Isso se cumpre na medida em que o sujeito encarnado vive da escuta, da (ob)audiência sem qualquer subserviência e do desejo do corpo de outrem como "cuidado de outrem". Só assim o Rosto não será vítima da injustiça do Ser, horizonte a partir do qual tudo se define e se compreende como se a alteridade se reduzisse a outra existência humana ao lado da qual não me encontro senão com outro Dasein no mundo a serviço do Ser.

\section{ENTRE A PROFÉTICA E A POÉTICA: O QUIASMA DA CARNALIDADE ÉTICA}

Graças à maneira ética e hiperbólica com que Lévinas diz a condição humana profética em função desse contato/linguagem avassalador de outrem, sua filosofia encontra ressonância nos escritos poéticos do grande literato mineiro João Guimarães Rosa. Portanto, nesse contexto, sua literatura se mostra inspiradora porque possibilita aproximar de maneira plástica da temática da antropologia da carne “de outro modo que Ser" (LÉVINAS, 2011, p. 78), assim como a propugna o filósofo lituano. Nesse sentido, é possível detectar uma espécie de quiasma entre a Poética de Guimarães Rosa e a Profética de Emmanuel Lévinas em função do protagonismo da alteridade de outrem que na "epifania do Rosto" (LÉVINAS, 1988, p. 49) faz-se mais próximo do sujeito que ele de si mesmo, a ponto de provocar uma fissura, senão, 
uma "físsão no núcleo da ipseidade da subjetividade" (LÉVINAS, 2011, p. 98) antes definida pela reflexividade ou pela sensibilidade da "autoafecção da vida" (1988, p. 56).

Além disso, há de se notar que em função da especificidade da intriga entre Poética e Profética em torno da Ética, a Filosofia da alteridade se prenuncia como aquele que se “edifica fora dos muros da ontologia e da hermenêutica” (LÉVINAS, 1982, p. 8). Afinal, a Ética se erige como Filosofia Primeira desbancando a pretensão da Ontologia de desvelar o sentido do humano à luz do Ser. Em contraposição à Ontologia, a filosofia da alteridade assume, por um lado, um estatuto pós-ontológico. Está calcada nesse Porvir (in)esperado de outrem que ao advir de outra margem se revela como Bem para além do Ser. Por esse motivo essa filosofia de outrem se coloca fora do horizonte do Ser. Em função dessa novidade focada na bondade do Rosto, constitui-se uma "saber" ancorado na relação com outrem indissociável de uma "sabedoria do amor" (LÉVINAS, 2011, p. 175). Diferente da filosofia grega como "amor à sabedoria", essa outra sabedoria está enraizada no evento ético do encontro euoutrem que situa para além do Ser no qual o Dasein se encontra ao serviço do Ser (p. 59).

Por outro lado, sua filosofia pode ser caracterizada como pós-hermenêutica. Ela não se circunscreve à pretensão "da decifração dos textos como se eles fossem todos da ordem da pura verbalização do Ser" ou de encontrar a existência autêntica do Dasein dedicado a cuidar do Ser (LÉVINAS, 1982, p. 10). Afinal, a "proximidade do outro é refratária à tematização refratária à reminiscência que sincroniza as fases de um passado. O inenarrável - outrem que perde na sua narração o seu rosto de próximo" (2011, p. 179). Por isso, a filosofia da alteridade põe toda ênfase na primazia da palavra, do apelo, da invocação, da saudação, da “comunicação imediata do Rosto" (1997a, p. 28), enfim, no Dizer ético de outrem que escapa da "compreensão" e se revela mais novo e mais antigo do que o Ser e sua linguagem graças à “auscultação" de outrem. Isso se explica porque segundo Lévinas, o Rosto revela o paradoxo [de certa desencarnação] de outrem diante do eu-corpo que o escuta.

Na relação social, certamente que a presença real do outro importe: mas, sobretudo, que esta presença, longe de significar a coexistência pura e simples comigo, longe de se explicar pela metáfora romântica da "presença viva" - se cumpre pela audição abstraindo seu sentido dessa função de origem transcendente que exerce a palavra proferida. É enquanto o verbo se recusa a tornar-se carne que ele assegura uma presença entre nós. A presença do Outro, é uma presença que ensina; é por isso que a palavra ensinamento é mais que a experiência do real e que o mestre é mais que um parteiro dos espíritos. (LÉVINAS, 1987, p. 220). 
Artigo: Entre a profética de Lévinas e a poética de Guimarães Rosa: uma antropologia da carne de outro modo que ser

Nesse caso, em se tratando de abordar filosoficamente a condição do ser humano como hospitalidade, responsabilidade e, em seguida, como "substituição e maternidade de outrem" (LÉVINAS, 2011, p. 94), trata-se de perceber como os textos da tradição podem fecundar não tanto a "imaginação e a memória" (p. 90) como enuncia a Filosofia hermenêutica, mas a "audição" daquele que se pretende aprendiz da "sabedoria do amor" (p. 175). Esta se contrapõe à conceptualização filosófica calcada no Ser porque o caráter genuinamente ético ou práxico da filosofia da alteridade precede todo saber existencial sem ética ou à ética hermenêutica calcada na ontologia. Colocar-se, pois, em contato na escuta das metáforas, símbolos, mitos, relatos, etc. em torno da outreidade do Rosto tais como se encontram condensados na obra literária parece fecunda para aquele que ousa debruçar-se sobre a humanidade profética (não poética) do ser humano à procura dessa "sabedoria do amor" que o Rosto dá a desejá-la a ponto de escavar na subjetividade o desejo de se conformar ao serviço do amor (de outrem). ${ }^{1}$ Portanto, o caráter filosófico-profético intrínseco à Literatura - por conta "da alteridade de outrem que se diz nela e que expõe o Mesmo à condição de ético-profética do ser humano" (LÉVINAS, 1982, p. 10) -, oferece um novo acesso àquilo que pretendemos propugnar como antropogênese da humanidade em consonância com o "humanismo do outro homem" (2012, p. 79). Esta se contrapõe à Humanitas (as humanidades) que Heidegger prometia levar a termo por meio da Ontologia (HEIDEGGER, 1967, p.78), isto é, ao imaginário do homem “pastor e cuidador do Ser” (p. 51), para ressaltar a ética do homem profeta cuidador do outro.

\section{A SABEDORIA PROFÉTICA E A LITERATURA DE GUIMARÃES ROSA}

Uma vez delineado o estatuto filosófico do humanismo do outro homem (LÉVINAS, 2012, p. 80) trata-se de dar outro passo em vista de aproximar do que se poderia denominar de "sabedoria profética" presente em Primeiras Estórias, obra de Guimarães Rosa, publicada em 1962. Destaca-se no conjunto dessa obra um conto magistral que o escritor o intitulou com o sugestivo nome de: A terceira margem do rio. Como se poderá logo intuir, o título evoca o

\footnotetext{
${ }^{1}$ Do contrário, se a filosofia se identificasse única e exclusivamente ao Logos como se acostumou a concebê-la no Ocidente desde Sócrates até Heidegger, estaria destinada a enfraquecer o Páthos e o Desejo do sujeito que a pratica. E ao permanecer na esteira dessa lógica ontológica, o sujeito poderia querer desistir de amar o profeta que o habita ou que se cola à sua pele. E sua justificativa viria do fato de que a filosofia encontra-se muito distante e alheia à experiência humana ao se entregar ao Ec-stase e ao gnosticismo da alteridade sem, contudo, chegar a experimentar o amor e a compaixão por outrem de carne e osso que ama e que sofre.
} 
caráter profético da humanidade uma vez que se evidencia a travessia de um homem a uma terceira margem, à margem do ser, na procura de outrem e não tanto em insistir "noutro modo de ser" jogado (derrelição) no rio da Existência.

Evidente, antecipar a trama de uma estória pode configurar-se como "uma traição do Dizer profético" (LÉVINAS, 2011, p. 29), pois compromete a força do drama traduzido em palavras que urge ser escutado por dentro; pelo leitor-vivente "em contato com a alteridade do outro no texto e do texto como uma alteridade" (1982, p. 127). Apesar disso, ousamos fazê-lo dado a urgência de se ter de pontuar as questões antropológicas fundamentais que somente "um texto profético para além do poético pode conter" (1982, p. 14). Visamos antecipar o fato de que o texto de Guimarães ponha o leitor em contato com uma "verdade per-seguida" na relação ética com outrem em detrimento da verdade ontológica ou da compreensão do Ser (LÉVINAS, 1982, p. 43). Aquela nos recordará que a Ética (fazer) precede e preside a Ontologia (pensar) e, não o contrário, tal como fomos habituados a pensar no Ocidente uma vez que somos filhos da Civilização da Razão.

De qualquer forma, resta aqui o convite para que o leitor se deixe simpatizar e seduzir pela literatura do romancista brasileiro dos outros sertões das Minas Gerais. E tomara, num futuro próximo, quem sabe consigamos fazer com que Guimarães Rosa seja lido e ensinado nas academias brasileiras como o grande filósofo contemporâneo da alteridade e do humanismo do outro homem ao lado de pensadores renomados como Jacques Derrida, Martin Buber, Franz Rosenzweig, Simone Weil e outros.

Depois dessas considerações resta recordar que, nesse conto, Guimarães Rosa narra a estória (im)possível - segundo a lógica do Ser - de um homem, nosso Pai, que habitava uma aldeia qualquer do sertão mineiro acompanhado da mulher e de seus três filhos. Cansado daquela ek-sistência "encomendou uma canoa especial, de pau de vinhático, pequena, mal com a tabuinha da popa, como para caber justo remador" (ROSA, 1968, p. 32). Até que um dia disse adeus à família, foi para o rio, entrou na canoa e nunca mais voltou. Doravante, sua vida consistia em navegar sozinho e em atravessar intransigente o rio sem margem alguma. A estória se tece em torno do drama vivido pela família e da transformação que essa partida provocou em cada um de seus membros.

Mas o ápice indissociável do desfecho da estória concentra-se em torno do encontro face a face do filho e de Nosso Pai. Melhor dizendo, da aproximação/linguagem do pai que, depois de muito tempo ausente deixa-se encontrar pelo filho, desse filho que jamais mergulhou no rio na indiferença à partida do pai. E nesse encontro dramático o pai, ao se 
Artigo: Entre a profética de Lévinas e a poética de Guimarães Rosa: uma antropologia da carne de outro modo que ser

fazer próximo do filho de fato consegue esvaziá-lo de sua essência, ou como diz Lévinas, terá provocado no filho uma espécie de desinter-essamento (LÉVINAS, 2011, p. 75) de seu ser fixado no papel e na linguagem de "ser" filho. Dito de maneira hiperbólica, essa aproximação do pai é como uma "sangria desatada" que não se estanca jamais uma vez que não há sutura para a ferida no corpo do sujeito (o filho) ao se sentir radicalmente golpeado pela "sorte" e pela "morte" de outrem (nosso Pai). Ora, essa situação da "deposição do eu", pode ser "auscultada" por meio das palavras dramáticas que o romancista põe na boca do filho (LÉVINAS, 1994, p. 158).

Sou o que não foi, o que vai ficar calado. Sei que agora é tarde, e temo abreviar com a vida, nos rasos do mundo. Mas, então, ao menos, que, no artigo da morte, peguem em mim, e me depositem também numa canoinha de nada, nessa água, que não para, de longas beiras: e, eu, rio abaixo, rio a fora, rio a dentro - o rio (ROSA, 1968, p. $37)$.

Enfim, depois de muito procurar o pai, o filho o avista à margem do rio. Pede para substitui-lo na navegação. O pai acena que sim, mas o filho foge desatinado porquanto considerava que o pai que o saudava vinha do além. A partir daí a vida do filho resumia-se em pedir perdão ao mesmo tempo em que se indagava se ainda era homem depois desse falimento...

Há, pois, de se enfatizar que a condição humana profética narrada por Guimarães Rosa à luz da filosofia de Lévinas, só apareça no fim da estória diante da indagação radical do filho sobre sua humanidade falida. Nesse sentido, vemo-nos interpelados por uma série de questões filosófico-existenciais que a poética se nos apresenta. Ora, não pretenderia o conto subrepticiamente nos introduzir no paradoxo próprio de outra lógica que rege o humanismo de outro homem? E nesse caso, não visaria alimentar outra indagação da ordem de um prólogo e fazer-nos perguntar: será que pelo fato de aceitar viver nessa condição falível de ter de pedir infinitamente perdão a outrem não revela a humanidade mais (des)humana em nós do que aquela calcada na infalibilidade do sujeito sem falta e, portanto, soberano em sua vontade de poder? Essa (des)humanidade não significaria exatamente o seu revés, isto é, o verdadeiro humanismo marcado pela destituição da essência graças à proximidade e à linguagem de outrem que conduz para além do ser?

O fato é que nesse encontro derradeiro e, talvez, o primeiro profeticamente vivido aos seus extremos, a relação com outrem se institui como a única chance - kairós - que se oferece ao homem de viver "fora de si", quase numa condição paradoxal que oscila entre uma psicose 
(loucura) e uma neurose (de culpabilidade extrema), explica Lévinas (2011, p. 157), sem que essa situação aparentemente ensandecida o faça perder sua lucidez e sua unicidade. Nesse sentido, as palavras de Guimarães Rosa se revelam inéditas.

Só fiz, que fui lá. Com um lenço, para o aceno ser mais. Eu estava muito no meu sentido. Esperei. Ao por fim, ele apareceu, aí e lá, o vulto. Estava ali, sentado à popa. Ele me escutou. Ficou em pé. Manejou remo n’água, proava para cá, concordado (ROSA, 1968, p. 36).

Segundo o filósofo lituano essa condição vulnerável de nossa humanidade se deve à inauguração do tempo, isto é, do Por-vir antecipado apenas pela vinda de outrem. Assim, a susceptibilidade do sujeito não se origina necessariamente da finitude ou da vida inautêntica revelada pelo ser, mas se deve à fenda, aos interstícios suscitados pelo olhar e pela palavra do outro que impacta o corpo do sujeito a ponto de ele tornar-se uma carnalidade ética. $\mathrm{O}$ advento de outrem cava grotas profundas na (sub)stância do sujeito de modo a semear no ventre/coração humano uma "espera contra toda esperança" (LÉVINAS, 1982, p. 45). Esta, por sua vez, só se justifica porque outrem passa e se passa como vestígio de "um Passado Imemorial, irrepresentável, pré-histórico, irrecuperável pela memória do sujeito” (2011. p. 59).

Trata-se aqui de uma passagem que assigna e sulca a subjetividade a ponto de enfraquecer sua "imaginação e memória" e sua pretensão de afirmar-se como atividade soberana segundo uma vontade capaz de dar-se a si mesma a possibilidade de um futuro no ser associando-o à chegada de outrem. Ora, o outro que passa e a atravessa não se sujeita a ser “intencionado" pela consciência bem como não se deixa ser "compreendido" à luz do Ser. Ele é "da ordem do (não)sentido porque deixa apenas rastos" (LÉVINAS, 2011, p. 33) de sua passagem na afecção que provoca em meu corpo. Afinal, a passagem do outro não se deixa reduzir a mais uma das múltiplas expressões do Ser para o qual todo e qualquer sentido passaria pelo crivo de seu dizer. Contra isso, o outro se posta fora, mas ao mesmo tempo se cola em mim sem distanciamento graças ao contato ético com sua proximidade. Ele, o Rosto, como "in" do infinito se põe dentro do sujeito finito a ponto de "o sujeito viver expulso de si mesmo" (LÉVINAS, 2011, p. 114); de ter de viver de pedir perdão por esse dom de outrem que não cabe na consciência; de ter de se ver impelido pela ideia do Rosto, pelo seu sopro ou por sua "inspiração" na passividade que esse sopro supõe (p. 131). Essa ideia do Rosto se instaura no corpo do sujeito como "pneuma do psiquismo" (p. 130). Daí que o sujeito/corpo 
Artigo: Entre a profética de Lévinas e a poética de Guimarães Rosa: uma antropologia da carne de outro modo que ser

vive somente de se deixar fazer carne numa espécie de substituição de outrem gestada como compaixão e perdão.

É, pois, como se o filho, cuja humanidade emerge de maneira plástica nas palavras do conto de Guimarães Rosa fosse convocado a tornar-se maternagem com relação ao seu pai. Isso se explica profeticamente porque somente fora do âmbito do ser, é possível romper com os papéis sociais, familiares, religiosos preconcebidos que assumimos ao longo de nossa existência. Dito de maneira positiva, na relação do face a face e do corpo a corpo assiste-se a uma subversão da "condição de filho para o de mãe de seu pai" graças à ética para além do Ser e à linguagem des-ontologizante pressuposta na auscultação ética de outrem.

Ora, para além de uma leitura psicanalítica, o sentido ético da subjetividade se revela "outra maneira que Ser" da humanidade tocada/dita por outrem. Esta não vive de cuidar do Ser, mas de abrigar na sua própria carne, o verbo (pneuma) do Rosto. Inabitação desse outro que se faz carne nas entranhas de misericórdia do feminino dessa subjetividade-fora-dosujeito-sem-reflexivo.

Na perspectiva profética, o humanismo do outro homem que se anuncia aqui se opõe criticamente às Humanidades da ontologia. Nesse horizonte, a existência humana só é bem vivida quando referida à autenticidade do Ser; do Ser como dom e não da subjetividade-forade-si remetida ao dom de outrem, Bem para além do Ser, que no contato com o sujeito torna seu corpo de carne na justiça, no perdão ou na bondade para outrem. Pois, é ele que esvazia a existência de seu inter-esse para fazer do corpo do sujeito carnalidade maternal vocacionada a cuidar da alegria, da dor e da mortal condição de outrem em sua susceptibilidade de próximo. $\mathrm{Na}$ esteira desse humanismo, a lógica ilógica que rege as relações é da ordem "do suportar, carregar o peso de outrem, cuja excelência é a maternidade" (LÉVINAS, 2011, p. 94). Tratase do subjectum irreflexivo instituído pelo outro num movimento de contração em suas entranhas como uma subjetividade-fora-si. Essa, sem poder pensar-se como sujeito lança-se ao rio a fim de salvar o outro do afogamento da existência do Ser, oferecendo-se a ele como dom ético na carne como movimento incessante de entrega do si-para-outrem.

Nesse sentido Guimarães Rosa insiste sobre a força desse trauma da aproximação/advento de outrem que provoca uma comoção nas entranhas do sujeito. Cumprese, assim, aquilo que Lévinas (1997b, p. 278) dizia "sobre outro modo que Ser" da humanidade como sensibilidade ética em contato com a pele de outrem exposta ao ultraje. um saudar de gesto - o primeiro, depois de tamanhos anos decorridos! E eu não 
podia...Por pavor, arrepiados os cabelos, corri, fugi, me tirei de lá, num procedimento desatinado. Porquanto que ele me pareceu vir: da parte do além (ROSA, 1968, p. 37).

Assim, a passagem de outrem ao inaugurar um tempo diacrônico (LÉVINAS, 2011, p. 102) - fora da sincronia do tempo existencial - em função dessa vinda que já se anuncia como adeus, provoca no corpo do sujeito uma inspiração (pneuma do psiquismo) a ponto de dizer-se na carnalidade como um-para-outrem (p.116). E sujeito inabitado pelo infinito torna-se carnepara-outrem, como signo dado a outrem no Eis-me aqui. Envia-me!

Essa carnalidade da subjetividade-fora-de-si, proferida pelo outro, se diz como responsabilidade, substituição, maternidade, compaixão. Não é à toa que Guimarães Rosa pode colocar na boca do filho aquilo que sintetiza a condição de subjectum à qual se refere Lévinas (2011, p. 131), quando diz que no contato de outrem não se escapa de se ter de suportar, carregar, substituir outrem.

Estava ali, de grito. Chamei, umas quantas vezes. E falei, o que urgia, jurado e declarado, tive que reforçar a voz: Pai, o senhor está velho, já fez o seu tanto...Agora, o senhor vem, não carece mais...O senhor vem, e eu, agora mesmo, quando que seja, a ambas vontades, eu tomo o seu lugar, do senhor, na canoa!... (ROSA, 1968, p. 36).

Porém, se no final do conto de Guimarães, tem-se a impressão de que o falimento da humanidade como condição profética se confirma no fato de o filho ter fugido e desesperado diante da aceitação e da passividade de outrem em se deixar cuidar, o fracasso parece só aparente. Na perspectiva levinasiana, é possível admitir que depois desse encontro decisivo, o filho jamais pudesse continuar a viver como se o "Nosso Pai", mesmo ausente não o interpelasse, não o afetasse com sua palavra. Essa palavra vinda do além inaugura o tempo do dom pelo qual o outro continua a perfurar os ouvidos da subjetividade-fora-de-si a fim de que ela se torne per-dom a outrem.

Em outras palavras, o filho jamais pode renunciar a sua identidade profética e proferida "testemunhada pela sua própria boca porque desde sempre havia sido eleito para substituir” o pai (LÉVINAS, 2011, p. 36). O filho como outro de si mesmo, nessa travessia interminável da humanidade à margem do ser não ousa descansar enquanto o outrem, Bem para além do ser, não seja acolhido em sua estrangeiridade de refugiado, abandonado, maltratado, excluído e desfigurado pela miséria e pelo anúncio da morte eminente. 
Artigo: Entre a profética de Lévinas e a poética de Guimarães Rosa: uma antropologia da carne de outro modo que ser

\title{
UMA LEITURA PANCRÔNICA DO EVENTO ÉTICO-LINGUÍSTICO
}

Retomando a narrativa de $A$ terceira margem do rio, indo do início para o fim, o fato de Nosso Pai emergir como um estranho em sua própria casa faz pensar que a humanidade de seus "entes queridos" supõe a acolhida de si mesmo em sua estrangeiridade, cujo sentido fora protagonizada na partida/adeus do Pai.

Sem alegria nem cuidado, nosso pai encalcou o chapéu e decidiu um adeus para a gente. Nem falou outras palavras, não pegou matula e trouxa, não fez a alguma recomendação. E nosso pai entrou na canoa e desamarrou, pelo remar. E a canoa saiu se indo - a sombra dela por igual, feito um jacaré, comprida longa. (ROSA, 1968, p. 32).

E isso se explica porque, segundo Lévinas, o outro não se deixa capturar nem classificar pelos atributos próprios de "ser" reconhecido como um "ser" humano. Por isso mesmo o Pai que nada falava, muito fala ao partir na canoa. Rompe-se assim o "imaginário" que o próprio filho teimava em manter a respeito do pai na sincronização de um "saber sensato" confirmado até pelos de fora da família:

\begin{abstract}
Nosso pai era homem cumpridor, ordeiro, positivo; e sido assim desde mocinho e menino, pelo que também testemunharam as diversas sensatas pessoas, quando indaguei a informação. Do que eu mesmo me alembro, ele não figurava mais estúrdio nem mais triste do que os outros, conhecidos nossos. Só quieto. Nossa mãe era quem regia, e que ralhava no diário com a gente - minha irmã, meu irmão e eu (ROSA, 1968, p. 32).
\end{abstract}

Doravante, no conto de Guimarães Rosto encontra-se no pai, o rosto de outrem, que de saída "bota a bênção e manda para trás", como um interdito de que não se pode poder sobre ele. E vai-se o Pai, para lugar outro, para alhures. Sempre perto, sempre distante, sempre à margem e nunca na margem. Como um outrem, causando estranheza e in-compreensão nos demais. Enquanto outrem ele é um "ente" que prescinde da referência ao Ser, diz Lévinas (1997a, p.31). Por isso não encontra sua significação senão em seu outrear como alteridade que interrompe incansavelmente a lógica injusta do Ser.

\footnotetext{
Nosso pai não voltou. Ele não tinha ido a nenhuma parte. Só executava a invenção de se permanecer naqueles espaços do rio, de meio a meio, sempre dentro da canoa, para dela não saltar, nunca mais. A estranheza dessa verdade deu para estarrecer de todo a gente. Aquilo que não havia, acontecia. Os parentes, vizinhos e conhecidos nossos, se reuniram, tomaram juntamente conselho (ROSA, 1968, p. 33).
} 
Sua significação advém de si mesmo como Rosto, isto é, fora do âmbito da Existência na qual se encontravam "jogados" seus familiares. Isso porque a imediação do encontro com o rosto excede qualquer compreensão, qualquer interpretação. E mesmo que se procure depois novas atribuições, o outro sempre escapa, desertando para outra sina a de existir.

\footnotetext{
Nossa mãe, vergonhosa, se portou com muita cordura; por isso, todos pensaram de nosso pai a razão em que não queriam falar: doideira. Outros achavam o entanto de poder também ser pagamento de promessa; ou que, nosso pai, quem sabe, por escrúpulo de estar com alguma feia doença, que seja, a lepra, se desertava para outra sina de existir, perto e longe de sua família dele (ROSA, 1968, p. 33).
}

Percebe-se a proximidade do rosto, tão perto em sua distância infinita; sente-se "a extra-territorialidade de outrem" (LÉVINAS, 1987, p. 185) nunca surgindo para "tomar terra" nem de noite nem de dia.

No que num engano. Eu mesmo cumpria de trazer para ele, cada dia, um tanto de comida furtada. No dia seguinte apareci. Enxerguei nosso pai, no enfim de uma hora, tão custosa para sobrevir: só assim, ele no ao-longe, sentado no fundo da canoa, suspendida no liso do rio. Me viu, não remou para cá, não fez sinal (ROSA, 1968, p. 33).

O rosto de outrem, como o Pai narrado por Guimarães Rosa, passa ao largo do rio do Ser, não nele "mergulhado" mas sobre ele, além dele. Equilibrando-se a todo custo para nele não se afogar e desaparecendo para outra banda sempre que dele tentam apropriar-se pela compreensão. É a essa situação que se somam as palavras ético-poéticas do filho no conto:

\footnotetext{
Nossa mãe jurou muito contra a ideia. Seria que, ele, que nessas artes não vadiava, se ia propor agora para pescarias e caçadas? Nosso pai nada não dizia. Sem alegria nem cuidado decidiu um adeus para a gente. Nem falou outras palavras, não pegou matula e trouxa, não fez a alguma recomendação. Nossa mãe mascou o beiço e bramou: Cê vai, ocê fique, você nunca volte! Nosso pai suspendeu a resposta. (ROSA 1968, p. 32).
}

O encontro com o próximo/linguagem que se faz próximo no Rosto é da ordem do encontro ético. E o acesso ao seu sentido advém da humanidade que se faz profética. Ora, ao interpelar anunciando a bondade e a paz e denunciando a injustiça (LÉVINAS, 1995, p. 149), o rosto de outrem investe o sujeito de uma culpabilidade pré-original. Nessa condição a subjetividade "não pode mais poder" viver na morada do Ser uma vez que seu corpo se torna - a impossibilidade da possibilidade - da própria inabitação de outrem. Doravante torna-se impossível formular qualquer juízo sobre outrem que diz adeus (ROSA, 1968, p. 36). E essa 
Artigo: Entre a profética de Lévinas e a poética de Guimarães Rosa: uma antropologia da carne de outro modo que ser

obrigação com relação a outrem não se diz violenta, pois ela não atinge a susceptibilidade do Eu.

Nessa esteira se entende a Ética não num viés ontológico, mas numa perspectiva da responsabilidade anterior à liberdade de escolha, graças à proximidade/linguagem do rosto de outrem. Essa responsabilidade traduz-se como um fazer-se corpo-para-outrem, estando no lugar de outrem. Não se trata de limitá-la a tirar da boca o alimento do qual se frui para dá-lo a outrem, mas de entregar a si mesmo como "corpo im-proprio" uma vez já inabitado por outrem. Por isso, na aproximação de outrem não se trata apenas de exercer a hospitalidade de um lugar oferecido a outrem, mas de ser pura sensibilidade, perdão num corpo que se faz signo no movimento de um-para-outrem. E nessa perspectiva já é possível vislumbrar o impacto que a ética exerce sobre a hermenêutica, pois o texto "altera" o leitor e o leva a agir de outro modo que Ser (LÉVINAS, 1997b, p. 286).

A guisa de conclusão urge afirmar que a hipérbole do contato suscitada pelo texto permite não apenas referir-se a ação, mas a uma "auscultação de sinais" advindos da aproximação/linguagem de outrem. A isso se deve o fato de que o texto provoque uma "defecção" na identidade do leitor (LÉVINAS, 2011, p. 107). Pelo fato de a escritura assumir um caráter eminentemente profético, todo ato de leitura tende a ferir e expulsar o leitor para fora de si. Isso desestabiliza o leitor, porque no encontro com a alteridade do texto acontece um colapso dos esquemas apriorísticos e pré-concebidos do leitor. Ele não sabe mais o que o ser lhe garante sobre a explicação e sobre a compreensão de si e do mundo do texto.

Disso decorre que o contato imediato no qual outrem se fala, embora o faça nas entrelinhas do texto, suspende não só o dia a dia do leitor, mas interrompe o horizonte de possibilidades que o Ser lhe oferecia. Há aqui uma dimensão do (in)esperado para o leitor uma vez que sensibilidade ética não se traduz apenas na escolha de possibilidades para a ação, mas em expor à ação/linguagem de outrem que o destitui (sujeito) da essência do ser. Em outras palavras, o texto deserta o leitor para "outra sina" que a de existir. Não por uma mimese do personagem, no caso, o pai que com uma canoa se lança no rio, ou o filho que vive em função do pai. Antes, o texto interpela ferindo o leitor a ter de agir outramente que o ser dos personagens, isto é, a agir como um Pai para aquele filho, ou a agir maternalmente na compaixão daquele pai.

Ao escutar, pois, o que o personagem não disse graças à ausência de outrem, o leitor percebe-se interpelado a responder ao Rosto tornando-se carne na ação, isto é, "en-carnação ética" (LÉVINAS, 1997b, p. 287). Nesse caso, supõe-se a aproximação/linguagem infinita de 
outrem como aquele que está sempre por-vir. E a espera da alteridade no texto suscita na subjetividade um desinteresse constante, a saber, ela deixa de ser apenas um "tempo-semlugar" de hospitalidade para outrem para tornar-se in-condição de subjectum graças ao outrono-mesmo cujo "tempo" se instaura como corpo-perdão-maternal-para-outrem (2011, p. 75).

Em suma, o texto sendo profético mesmo em seu caráter poético apresenta ao leitor o grande "sim" de outrem que golpeia os ouvidos pedindo para ser querido, amado, cuidado. Contudo, trata-se de um amor que se destitui de todo imaginário romântico. E Guimarães Rosa o traduz em seu escrito ao apresentar o filho que, depois de tantos anos de espera, foge do pai, que se lhe aproxima e que se lhe fala ao coração, no âmago da carnalidade humana. Quando se pensava que o filho assumiria o lugar do pai, o amaria e cuidaria dele, eis que o texto traumatiza o leitor a ponto de suscitar nele um vácuo, uma ausência que o desarvora não restando senão dizer com o corpo “Eis-me aqui” (LÉVINAS, 2011, p. 157).

Afinal, o filho - como o pai - evoca a figura daquele que está sempre de partida, qual um arameu errante cujo personagem encontra na escritura levinasiana seu protótipo em Abraão. Este representa a humanidade que um dia deixou sua terra natal sem alimentar qualquer expectativa de retorno ao que já se foi ou qualquer ímpeto nostálgico de volta à sua pátria. Nesse caso, trata-se do anti-herói se comparado à figura de Ulisses. No imaginário da civilização grega, sobressai o fato de que ele, depois de cada conquista e de cada guerra, volta vitorioso a Ítaca para celebrar a destruição de outrem.

Contra essa perspectiva da humanidade beligerante, expropriante e violenta, configura-se "outro modo que Ser" da subjetividade-fora-de-si, à qual nos põe em confronto com o texto profético. É, pois, a essa humanidade marcada pelo proferimento de outrem e mobilizada pela "sabedoria do amor a serviço do amor" (LÉVINAS, 2011, p. 69) que nos remete a profética da escritura do outro. Trata-se de se deixar instruir e inspirar e tornar-se carne a serviço do corpo frágil de outrem a fim de que ele não pereça em sua nudez e em sua susceptibilidade de próximo.

E só depois de ter respondido prontamente ao amor a outrem (ético), amor da ordem do Desejo do Indesejável, é que o profeta dá-se conta de que esse Dito - que ele só ouve depois de o haver proclamado pela sua própria boca -, foi precedido e inspirado pelo Dizer ético do Rosto que o feriu. Sem esse (pro)ferimento de outrem que tudo antecipa, a humanidade (subjetividade) jamais se saberia como profeta a serviço da palavra e da linguagem de outrem que sempre extrapola a poética da ontologia. 
Artigo: Entre a profética de Lévinas e a poética de Guimarães Rosa: uma antropologia da carne de outro modo que ser

\section{REFERÊNCIAS}

HEIDEGGER, Martin. Sobre o Humanismo. Rio de Janeiro: Tempo Brasileiro, 1967.

LÉVINAS, Emmanuel. Altérité et transcendance. Paris: Fata Morgana, 1995.

LÉVINAS, Emmanuel. De outro modo que ser ou para lá da essência. Lisboa: Centro de Filosofia da Universidade de Lisboa, 2011.

LÉVINAS, Emmanuel. Descobrindo a existência com Husserl e Heidegger. Lisboa: Instituto Piaget, 1997b.

LÉVINAS, Emmanuel. Entre nós. Ensaios sobre a alteridade. Petrópolis, RJ: Vozes, 1997a.

LÉVINAS, Emmanuel. Hors sujet. Paris: Fata Morgana, 1987.

LÉVINAS, Emmanuel. Humanismo do outro homem. Petrópolis, RJ: Vozes, 2012.

LÉVINAS, Emmanuel. L'au-delà du verset. Lectures et discours tamudiques. Paris. Editions de Minuit, 1982.

LÉVINAS, Emmanuel. Les imprévus de l’histoire. Paris: Fata Morgana, 1994.

LÉVINAS, Emmanuel. Totalidade e infinito. Lisboa: Edições 70, 1988.

ROSA, João Guimarães. Primeiras estórias. Rio de Janeiro: José Olympio, 1968. 